\title{
Influence of sediment transport on short-term recolonization by seamount infauna
}

\author{
Lisa A. Leviin, Claudio DiBacco \\ Marine Life Research Group, Scripps Institution of Oceanography, La Jolla, California 92093-0218, USA
}

\begin{abstract}
Rates and mechanisms of infaunal recolonization in contrasting sediment transport regimes were examined by deploying hydrod ynamically unbiased colonization trays at 2 sites $\sim 2 \mathrm{~km}$ apart on the flat summit plain of Fieberling Gulyot in the eastern Pacific Ocean. Both study sites experienced strong bottom currents and high she ar velocity ( $u$. exceeding $1.0 \mathrm{~cm} \mathrm{~s}^{-1}$ daily). Macrofaunal recolonization of defaunated sediments on Fireberling Guyot was slow relative to observations in shallow-water sediments, but rapid compared to other unenriched deep-sea treatments. Microbial colonization was slower but macrofaunal colonization was faster at White Sand Swale (WSS, 585 m), where rippled foraminiferal sands migrate daily, then at Sea Pen Rim (SPR, $635 \mathrm{~m}$ ), where the basaltic sands move infrequently. Total densities of macrofasnal colonizers at WSS were 31 and $75 \%$ of ambient after 7 wk and $6.4 \mathrm{mo}$, respectively; at SPR they were 6 and $49 \%$ of ambient, respectively. Over $3 / 4$ of the colonists were polychaetes (predominantly hesionids and dorvilleids) and aplacophoran molluscs. Species richness of colonizers was comparable at SPR and WSS and did not differ substantially from ambient. Most of the species (91\%) and indriduals (95\%) recovered in colonization trays were taxa present in background cores. However, only $25 \%$ of the taxa colonizing tray sediments occurred in trays at both WSS and SPR. Sessile species, carnivores and surface feeders were initially slow to appear in colonization trays, but after $6.4 \mathrm{mo}$, colmizer feeding modes, life habits and mobility patterns mirrored those in ambient sediments at WSS and SPR. Defaunated sediments were colonized by larvae, juveniles and adults at both sites. These experiments provide the first observations of infaunal colonization on seamounts, and in deep, high-energy settings. Passive bedload transport appears to be a dominant colonization mechanism in unstabie foraminiferal sands at WSS. Based on the rapid recovery of infauna in trays and low diversity at WSS, we infer that disturbance is a natural feature of this site and that the ambient fauna of WSS retains factures of early succession. Infaunal colonization is slower in the stable substrate at SPR, where physicall disturbance may occur much less frequently.
\end{abstract}

KEY WORDS: Colonization rates - Disturbance - Soft-bottom - Succession - Fieberling Guyot $\cdot$ Highenergy regime - Macrofauna S Seamount . Sed ment transport - Vertical distribution

\section{INTRODUCTION}

Disturbance is a ubiquitous feature of marine and terrestrial environments (Pickett \& White 1985, Giller et al. 1994). In marine soft sediments, natural disturbance can be a significant structuring agent and has recently been reviewed by Hall (1994) for shalløw sediments and by Grassle \& Grassle (1994), Rice \& Lambshead (1994) and Smith (1994) for the deep-siea floor. Initial faunal recovery processes following mâj or disturbance are referred to as colonization, which is followed by succession. They influence many aspects of community structure including diversity, dominance and guild structure, as well as competitive, trophic and symbiotic interactions (Smith 1994). Successional studies of recovery rates and mechanisms provide basic understanding of community organization. They also are necessary for practical management of seabed resources that experience degradation from pollution or are subject to commercial exploitation.

Most studies of disturbance and infaunal recovery in soft sediments have been conducted in relatively quiet, low-flow settings, either in shallow subtidal and intertidal estuarine sediments (Thistle 1981) or in the deep sea (Smith \& Hessler 1987). These studies have focused on factors such as patch size, type, location, organic 
enrichment, or hydrodynamic artifacts that influence the rate of recovery to ambient densities and changes in species composition. The consequences of successional events, including changes in physical and geochemical properties of sediments, community diversity or competition and predation, also have been examined (Rhoads \& Boyer 1982, Hall 1994).

Few colonization studies have been carried out in high-energy regimes. The significance of hydrodynamic regime and sediment transport to soft-bottom colonization has been addressed primarily in the context of microtopographic variation (Savidge \& Taghon 1988, Snelgrove 1994), colonization tray artifacts (Smith 1985, Snelgrove et al. 1992) or postlarval transport (Emerson \& Grant 1991). To our knowledge there have been no direct, community-level comparisons of macrofaunal colonization processes in local regimes with differing sediment transport, although some meiofaunal studies have addressed this issue (Palmer 1988).

Seamounts represent a deep-water setting where strong bottom currents are common. The abrupt topography of seamount flanks and summits interacts with internal tides and waves to produce amplified flows (Roden 1987, Noble et al. 1988, Genin et al. 1989, Noble \& Mullineaux 1989, Brink 1990, Eriksen 1991). Because substrate composition and thus particle density can be highly heterogeneous on seamounts (Levin \& Nittrouer 1987), strong bottom flows can induce regular sediment transport at one site but not another (Levin et al. 1994a). This heterogeneity permits us to address hypotheses about the influence of substrate motion on colonization processes. Small-scale ( $\mathrm{cm}$ to $\mathrm{m}$ ) disturbances on seamounts include disruption of surface sediments by epifauna (crabs, echinoids, holothurians, ophiuroids), mound-forming megafauna, bottomfeeding fishes, sharks or cetaceans and by ripple and dune migration (Levin \& Nittrouer 1987, Kaufmann et al. 1989, Reimers \& Wakefield 1989).

We examined colonization of disturbed (defaunated) sediments at 2 sites located $2 \mathrm{~km}$ apart on the summit of Fieberling Guyot (eastern Pacific Ocean), one experiencing sediment transport daily and one with relatively stable sediments. The null hypotheses were that there would be no difference in colonization rates, colonizer composition or colonization mechanisms between the 2 sites, i.e. that assemblages at both sites exhibit similar responses to disturbance. Our alternative hypothesis was that the assemblage naturally subject to regular sediment transport should recover from disturbance faster than the other, primarily through colonization by juveniles and adults in the background community. Larval recruitment was predicted to be the primary colonization mechanism in stable sediments.

Previous colonization studies on seamounts have concentrated solely on hard substrates (Mullineaux \&
Butman 1990, Verlaan 1992, Bertram \& Cowen 1994). There have been few experimental data aimed at understanding soft-bottom colonization events either in high-flow regimes or at upper slope depths. The Fieberling Guyot studies described here contribute information in both regards and provide a contrast to previous work in shallow-water, high-energy systems as well as in bathyal, quiescent systems.

\section{METHODS}

Study site description. Colonization studies were carried out in sediments at 2 sites atop the flat summit plain of Fieiberling Guyot, a conical seamount located $992 \mathrm{~km}$ west of San Diego, California, USA. These sites are high-energy, coarse-grained settings that differ primarily in substrate composition and mobility. The biological, sedimentological and flow characteristics of the 2 study sites, Sea Pen Rim (SPR) and White Sand Swale (WSSI. are described in detail in Levin et al. (1994a). SPR $132^{\circ} 27.631^{\prime} \mathrm{N}, 127^{\circ} 49.489^{\prime} \mathrm{W}$ ), named for densities $>1 \mathrm{~m}^{-2}$ of the sea pen Pennatula sp., is located on the western rim of the summit plain at $635 \mathrm{~m}$. Primarily, sediments are poorly sorted basaltic sands with a mean grain size of 370 to $530 \mu \mathrm{m}$ (Table 1). Nonbasaltic grains are composed of foraminiferan tests and siliceous sponge spicules. WSS $\left(32^{\circ} 27.581^{\prime} \mathrm{N}\right.$, $127^{\circ} 47.839^{\circ} \mathrm{W}$ ) is located $-2 \mathrm{~km}$ east of SPR, nearer the center of the summit plain at $580 \mathrm{~m}$. Sediments are predominantly rippled foraminiferal (globigerinacean) sands with a mean grain size of 340 to $430 \mu \mathrm{m}$ (Table 1).

During the period of investigation (October 1990 to June 1991) bottom currents and shear velocities were similar at the 2 sites (Levin et al. 1994a, T. Gross unpubl.). Benthic acoustic stress sensor (BASS) current measurements made $4.4 \mathrm{~m}$ above the bottom (mab) on October 21 to 24, 1990, at WSS and on December 7 to 14, 1990, at SPR revealed a strong diurnal tidal signal

Table 1. Characteristics of study sites on the summit plain of Fieberling Guyot. Means (SD in parentheses)

\begin{tabular}{|c|c|c|}
\hline & $\begin{array}{l}\text { Sea Pen Rim } \\
\quad 635 \mathrm{~m}\end{array}$ & $\begin{array}{l}\text { White Sand Swale } \\
\qquad 580 \mathrm{~m}\end{array}$ \\
\hline$\%$ Sand $(>63 \mu \mathrm{rr})$ & $93.1(2.1)$ & $96.0\{3.0\}$ \\
\hline$\% \mathrm{CaCO}_{3}$ & $19.9(9.6)$ & $82.4(6.7)$ \\
\hline$\%$ Organic C & $0.13(0.03)$ & $0.12(0.03\}$ \\
\hline$C: N$ & $8.16(1.39)$ & $8.31(0.64)$ \\
\hline Dominant gran type & Basalt & Foraminiferan test \\
\hline Density $\left(\mathrm{g} \mathrm{cm}^{-3}\right)$ & 1.8 & 2.7 \\
\hline $\begin{array}{l}\text { Critical shear velocity } \\
\left(u \cdot \mathrm{crit}^{\mathrm{a}} \mathrm{cm} \mathrm{s}^{-1}\right)\end{array}$ & 1.0 & 1.5 \\
\hline \multicolumn{3}{|l|}{${ }^{\text {a}}$ From Levin et al. (1994a) } \\
\hline
\end{tabular}


with current speeds frequently exceeding $10 \mathrm{~cm} \mathrm{~s}^{-1}$ and occasionally exceeding $20 \mathrm{~cm} \mathrm{~s}^{-1}$ at both sites. Shear velocities ( $u$.) exceeded $0.5 \mathrm{~cm} \mathrm{~s}^{-1}$ and $1.0 \mathrm{~cm} \mathrm{~s}^{-1}$ $40 \%$ and $4 \%$ of the time, respectively, at SPR and $45 \%$ and $10 \%$ of the time, respectively, at WSS. A full year of Acoustic Doppler Current Profiler (ADCP) data from $18 \mathrm{mab}$ at a site between and slightly north of our study sites indicated that current speeds in October 1990 (corresponding to the WSS measurements) were typical of those observed the entire year, while December 1990 currents (corresponding to the SPR measurement period) were somewhat faster than the yearly average (Wichman et al. 1993).

Despite similar bottom stresses at WSS and SPR, differences in sediment composition and grain density led to different critical shear velocities and produced contrasting sediment transport regimes. The critical shear velocity required to move the modal grain size at WSS was about $1.0 \mathrm{~cm} \mathrm{~s}^{-1}$ (Levin et al. 1994a). During the study period, surficial sediments in the modal size class at WSS were estimated to move on average $10 \%$ of each day. During the strongest flows measured, up to $95 \%$ of the surface grains would have been in motion. At SPR, critical shear velocity of the modal grain size was estimated to be $1.53 \mathrm{~cm} \mathrm{~s}^{-1}$. The maximum shear velocity calculated from BASS measurements at SPR, $1.4 \mathrm{~cm} \mathrm{~s}^{-1}$, was not sufficient to set the modal grain size in motion. During the strongest current flows measured, a maximum of $15 \%$ of the surficial grains might have been transported, although less transport of fine particles probably occurred due to armoring of the bed by coarser grains (Levin et al. 1994a).

Indicators of infaunal food supply, such as sediment organic $\mathrm{C}$ and $\mathrm{N}$ content, and bacterial counts, did not differ significantly between WSS and SPR during the period of study. Levin et al. (1994a) report that macrofaunal densities (infauna $>0.3 \mathrm{~mm}$ ) were similar at WSS and SPR in December 1990 and June 1991, but were higher at WSS in October 1990.

Colonization experiments. The colonization trays deployed were identical to those described by Snelgrove et al. (1992). The apparatus contains a sediment-filled bag (20 $\mu \mathrm{m}$ mesh) within a bottomless and partially sideless nylon cup $(11.4 \mathrm{~cm}$ diameter, $102 \mathrm{~cm}^{2}$ area, $10 \mathrm{~cm}$ deep) that is surrounded by a flat, $40 \mathrm{~m}$ diameter Delrin nylon collar. The collar and central cup were nestled into the sediment so that the upper surfaces were flush with the sediment-water interface (Fig. 1a) Water-tight deployment and recovery lids were secured with nylon posts protruding at the edge of the tray. These lids were designed so that a submersible could deploy and recover the trays without loss or addition of sediment or animals. The broad collar and posts were designed to produce minimal flow disruption over the sediment-filled cup. Laboratory flume measurements, made under conditions of $u . \approx 0.5 \mathrm{~cm}$ $\mathrm{s}^{-1}$ (the mean $u$. at our study sites), verified this to be the case (Snelgrove et al. 1992, Snelgrove 1993). It was not possible to obtain a flush surface for all trays during deployment and a few were elevated up to $1.5 \mathrm{~cm}$ above the sediment surface. Snelgrove et al.'s (1992) flume measurements suggest that even when such flow disruption occurs at the lip of the collar, smooth
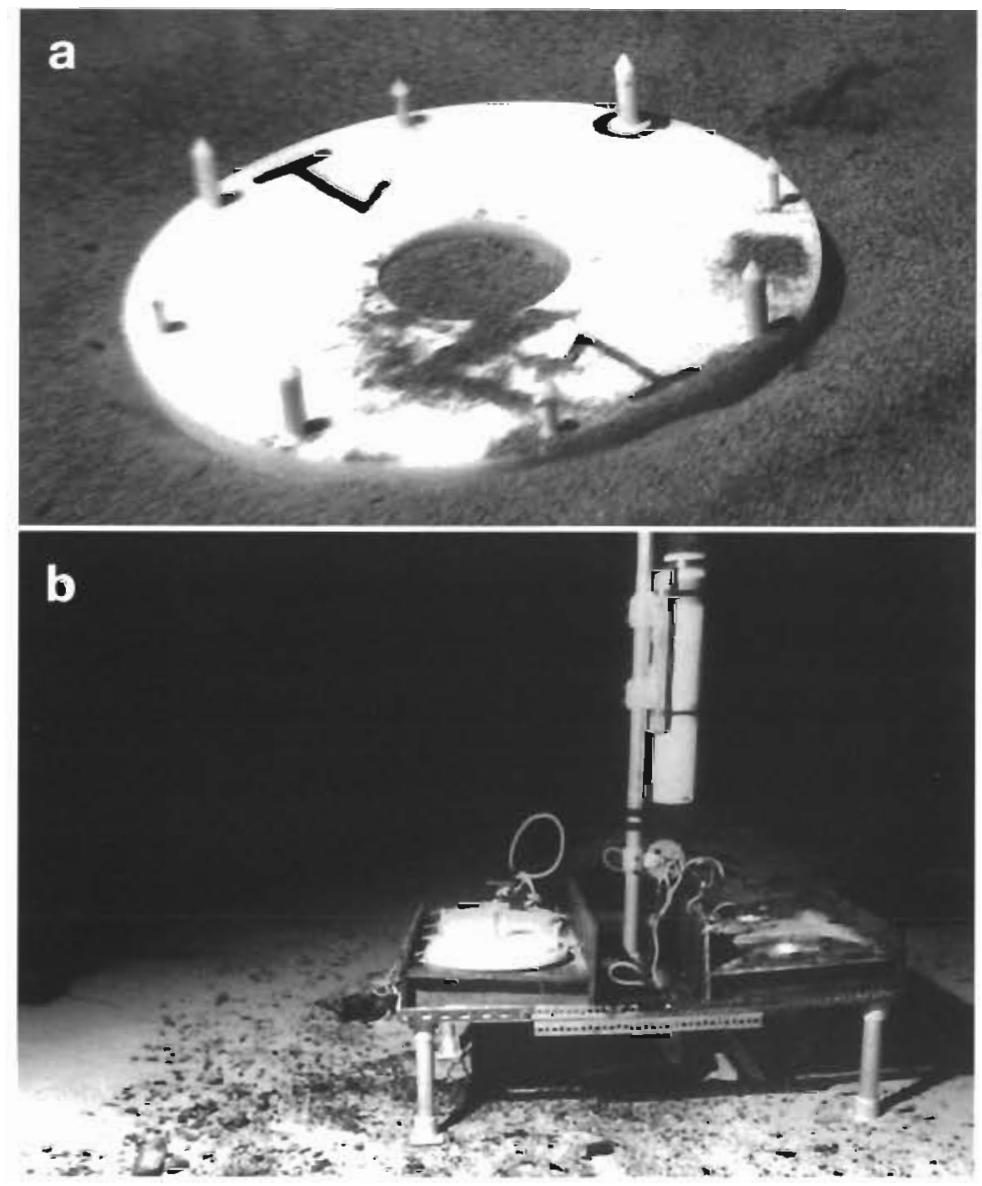

Fig. 1. (a) Colonization tray in situ at White Sand Swale on the summit plain of Fieberling Guyot, $580 \mathrm{~m}$. Diameter of the Delrin collar is $40 \mathrm{~cm}$. Diameter of the cup filled with defaunated sediments is $11.4 \mathrm{~cm}$. (b) Gear elevator used to transport colonization trays to and from the floor of the Fieberling Guyot summit plain. The elevator was deployed as a free vehicle from the surface ship and manually released from tho bottom by ALVIN. Two trays with deployment lids are still in place on the gear elevator 
flow is reestablished over the sediments in the central cup.

Sediments used in the colonization trays were obtained with the submersible 'ALVIN' by collecting surface sediments (top $10 \mathrm{~cm}$ ) from SPR and WSS with a scoop bag. Once on board ship these sediments were defaunated by heating them to approximately $30^{\circ} \mathrm{C}$ in the engine room for 12 to $24 \mathrm{~h}$, then freezing them at $-70^{\circ} \mathrm{C}$ for $24 \mathrm{~h}$ and thawing them before deployment.

Sediment trays were transported to and from the sea floor with a gear elevator designed to hold 4 trays (Fig. 1b). The elevator containing trays ready for placement was deployed immediately prior to each ALVIN launch. Eckman-style box cores (dimensions $15 \times 15 \times$ $15 \mathrm{~cm}$ ) were taken to make holes for the trays and to provide background (hereafter referred to as ambient) data for the colonization experiments. After placement into the sediment, the tray's deployment lid was removed to expose the central sediment cup. At recovery a lid was placed by ALVIN over the sediment surface and the tray was carried upright to the gear elevator and secured. The elevator containing newly recovered trays was sent up and brought aboard ship for processing prior to ALVIN surfacing. Thus colonization trays spent minimal time (generally 1 to $3 \mathrm{~h}$ ) under water with deployment or recovery lids attached.

Colonization trays were deployed for 2 periods of time. The first lasted approximately 7 wk (47 to 52 d), from October to December 1990; the second lasted for approximately $6.4 \mathrm{mo}$ ( 44 to $46 \mathrm{~d}$ ), from December 1990 to June 1991. Six trays were deployed at each site in October 1990 and 4 were deployed at each site in December 1990. All were recovered successfully except for one (i.e. SPR, December 1990) whose contents were lost during recovery. Trays were placed haphazardly over a region $100 \times 25 \mathrm{~m}$ at SPR and $150 \times 25 \mathrm{~m}$ at WSS.

Sample processing and analysis. Once trays were recovered, the sediment-filled cups were unscrewed from the collar and sediments were extruded and sectioned vertically at $0-1,1-2,2-5$ and $5-10 \mathrm{~cm}$ intervals. Sediments were preserved unsieved in $8 \%$ buffered formalin and seawater for later analysis of infauna. Eckman-style boxcores (penetrated to $10 \mathrm{~cm}$ depth), taken to record ambient faunal composition at the beginning and end of each tray deployment period, were divided into quarters and processed in a similar manner. Boxcores were either tray holes (October 1990 and December 1990) or control cores taken within $2 \mathrm{~m}$ of the recovered tray (December 1990 and June 1991). The entire contents of each $102 \mathrm{~cm}^{2}$ tray recovered in December 1990 ( $7 \mathrm{wk}$ ) were processed for infauna. In June 1991, one-eighth of the contents of the 6.4 mo trays (a $45^{\circ}$ wedge) was isolated and subsampled for use in making acridine orange direct counts (AODC) of bacteria using a $1 \mathrm{~cm}$ diameter glass tube. These sediments were sectioned vertically at $1 \mathrm{~cm}$ intervals. The $0-1,2-3,5-6$ and $9-10 \mathrm{~cm}$ intervals were preserved in $2 \%$ glutaraldehyde and $0.2 \mu \mathrm{m}$ filtered seawater. Bacterial counts were carried out with epifluorescence microscopy as described in Levin et al. (1994a).

In the laboratory, infaunal samples from colonization trays and boxcores were sieved on a $300 \mu \mathrm{m}$ screen. Animals and sediments retained were sorted under a dissecting microscope at 12 to $50 \times$ magnification and identified to the lowest taxon possible, then preserved in $70 \%$ ethanol. One-half (2 subsamples) of each boxcore was analyzed for infaunal abundance and composition.

The surface area examined $\left(112.5 \mathrm{~cm}^{2}\right)$ for each Eckman core was about $10 \%$ greater than the sediment surface area of each colonization tray. Comparisons between colonization tray and ambient boxcore densities were made by converting all densities to counts per $100 \mathrm{~cm}^{2}$

Error terms presented with mean count data are standard errors unless otherwise specified. Pairwise comparisons of parameters between sites (SPR vS WSS), treatments (tray vs ambient) and exposure times ( 7 wk vs $6.4 \mathrm{mo}$ ) were made using $t$-tests (JMP software, SAS, Inc.). Homogeneity of variance was examined with Bartlett's test. When variances were heterogeneous, data were square root or log transformed and retested. All percentage data were arcsine transformed prior to analysis. Rarefaction curves were generated using the methods described in Hurlbert (1971) to examine species richness in colonization tray and ambient assemblages.

\section{RESULTS}

\section{Microbial counts}

Colonization tray sediments exposed for 6.4 mo (recovered in June 1991) yielded higher acridine orange counts of bacteria per $\mathrm{ml}$ at SPR than at WSS in the $0-1 \mathrm{~cm}\left(1.40 \pm 0.08 \times 10^{8}\right.$ at SPR, $0.97 \pm 0.10 \times 10^{8}$ at WSS; $\mathrm{p}=0.013$; Fig. 2$)$ and $2-3 \mathrm{~cm}$ fractions $\left(1.27 \pm 0.03 \times 10^{8}\right.$ at SPR, $0.85 \pm 0.06 \times 10^{8}$ at WSS; $\left.\mathrm{p}=0.001\right)$. However, these differences did not penetrate below $5 \mathrm{~cm}$ depth in the sediment column. Bacterial counts at $5-6 \mathrm{~cm}$ in the sediment trays were $0.65 \pm 0.13 \times 10^{8}$ at SPR and $0.65 \pm$ $0.05 \times 10^{8}$ at WSS $(\mathrm{p}=0.963)$. At WSS mean surface bacterial counts in colonization trays were $28 \%$ lower than in ambient sediments $\left(0.97 \pm 0.10 \times 10^{8}\right.$ vs $1.36 \pm 0.24 \times$ $\left.10^{8}\right)(p=0.032)$. However, at SPR surface counts in trays $\left(1.40 \pm 0.08 \times 10^{8}\right)$ and ambient sediments $(1.73 \pm 0.10 \times$ $10^{8}$ ) did not differ significantly ( $\left.p=0.062\right)$ (Fig. 2). 


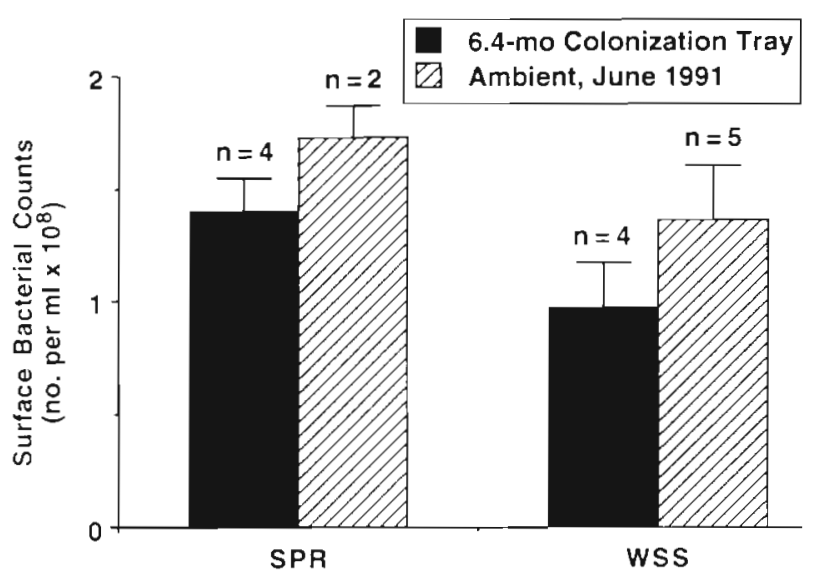

Fig. 2. Acridine orange counts of bacteria (mean $+1 \mathrm{SE}$ ) in colonization trays containing defaunated sediments exposed for $6.4 \mathrm{mo}$ (December 1990 to June 1991) and in ambient sediments sampled in June 1991 from Sea Pen Rim (SPR, $635 \mathrm{~m}$ ) and White Sand Swale (WSS, $580 \mathrm{~m}$ ) on the summit plain of Fieberling Guyot. t-tests comparing counts at SPR vs WSS were $p=0.01$ for trays and $p=0.09$ for background sediments $t$-test comparing tray counts with ambient counts were $p=0.03$ at WSS and $p=0.06$ at SPR

\section{Infaunal colonization patterns}

\section{Densities}

During the 7 wk experiment, infaunal colonization of trays was more rapid at WSS than SPR (Figs. 3a \& 4a). Macrofaunal densities were $6 \times$ higher at WSS than SPR ( $p=0.003)$. These densities were significantly below October and December 1990 ambient levels at both sites ( $\mathrm{p}<0.001$ at WSS, $\mathrm{p}<0.015$ at SPR) (Fig. 3a). The tray assemblage attained 31 and $6 \%$ of December 1990 ambient densities at WSS and SPR, respectively. Of the 11 major taxa depicted in Fig. $4 \mathrm{a}$, only colonizing polychaetes $(p=0.007)$ and aplacophorans $(p=$ 0.012 ) had higher densities in trays at WSS than SPR. None of the 11 taxa exhibited significantly higher densities at SPR than WSS (Fig. 4a). When the experiment was initiated in October 1990, total infauna, polychaetes, aplacophorans, and turbellarians were more abundant in undisturbed sediments of WSS than of SPR (Levin et al. 1994a). However, at the time of tray collection (December 1990) ambient macrofaunal and polychaete densities at the 2 sites did not differ (macrofauna $=16.0$ ind . per $100 \mathrm{~cm}^{2}$ at SPR and 16.2 ind. per $100 \mathrm{~cm}^{2}$ at WSS). Aplacophorans remained more abundant in ambient sediments at WSS than SPR $(p=0.043)$, while peracarid crustaceans $(p=0.040)$ and echinoderms ( $p=0.009$ ) were more abundant at SPR.

Colonization trays collected in June 1991, after 6.4 mo exposure, had $1.8 \times$ more macrofauna at WSS than SPR but mean macrofaunal densities were not significantly different between sites $(p=0.087)$ (Fig. 3b). Densities of the 11 major taxa shown in Fig. $4 \mathrm{~b}$ did not differ significantly in trays at SPR and WSS. Ambient densities of total macrofauna did not differ between sites at the time of tray deployment (see above) or collection (18.96 ind. per $100 \mathrm{~cm}^{2}$ at SPR, 17.17 ind. per $100 \mathrm{~cm}^{2}$ at WSS). After 6.4 mo exposure, the trays attained $49 \%$ of ambient (June 1991) densities at SPR and $75 \%$ of ambient densities at WSS. At WSS, 6.4 mo tray densities did not differ significantly from ambient densities at the time of recovery for total macrofauna $(p=0.155)$, whereas at SPR total colonizer densities remained below June 1991 ambient levels $(p=0.011)$. Few differences were observed between undisturbed and colonization tray sediments among individual taxa, in part because densities and statistical power were low. In the 6.4 mo exposure at SPR, oligochaetes were significantly reduced in trays at SPR relative to ambient sediments $(\mathrm{p}=0.042)$.
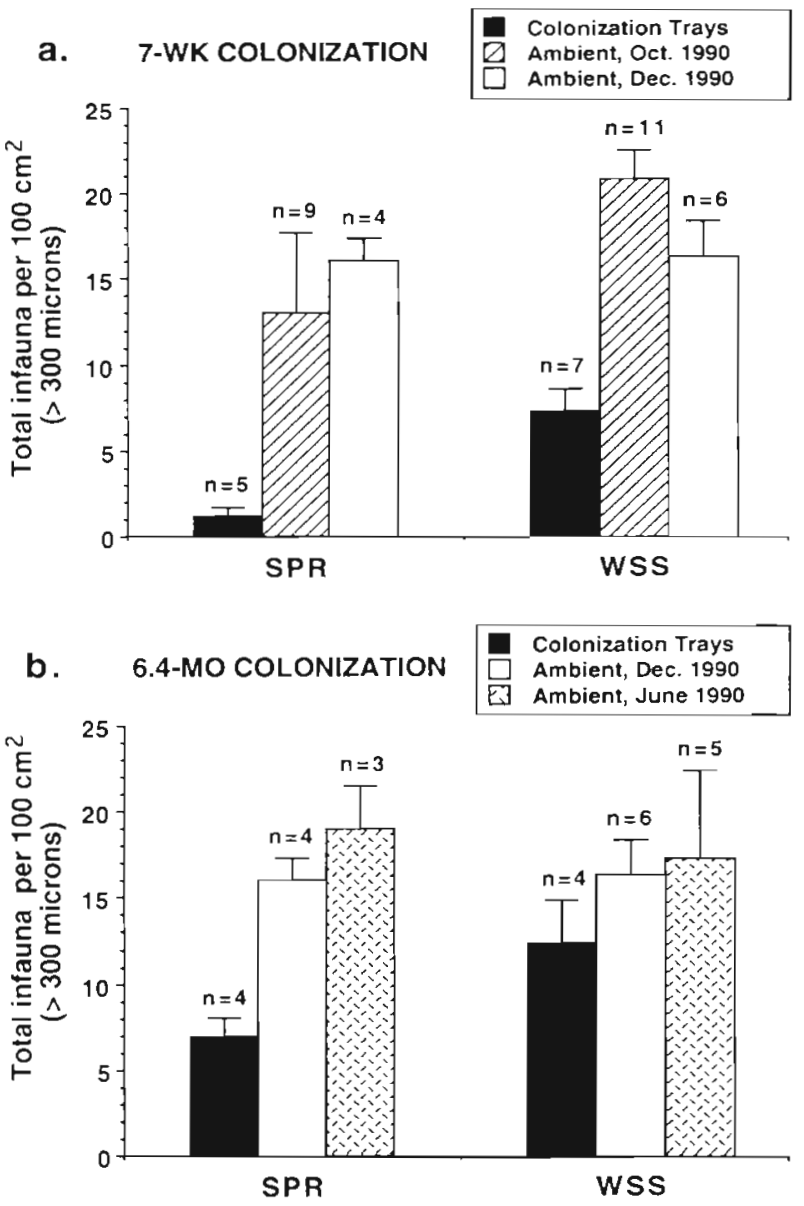

Fig. 3. Densities of total infauna (mean $+1 \mathrm{SE},>300 \mu \mathrm{m}$ ) in colonization trays and in background sediments at the start and end of the colonization experiments. (a) 7 wk experiments, (b) 6.4 mo experiments. SPR: Sea Pen Rim, $635 \mathrm{~m}$; WSS: White Sand Swale, $580 \mathrm{~m}$ 
Colonizer composition and species richness

Representation of major taxa was generally similar in trays at the 2 sites, with polychaetes and aplacophoran molluscs being the most frequent colonizers (Table 2, Fig. 4a). However, aplacophorans, which were absent from the short-term trays at SPR, were significantly more abundant at WSS after $7 \mathrm{wk}(\mathrm{p}=$ 0.012) (Fig. 4a).

Thirty-two species were recovered in colonization trays with an additional 4 groups of polychaete juveniles that were too small for species-level identification (ampharetids, syllids, hesionids and others). Of the identified species, all but 3 (4 individuals representing $5 \%$ of colonizers) were present in ambient sediments sampled from SPR and WSS. More species colonized trays at WSS than at SPR (Table 2). Rarefaction analyses yielded nearly identical species richness curves for colonists at the 2 sites (Fig. 5).

Despite general between-site similarity of major colonizing taxa (Fig. 4), only 9 of the 32 identified species in trays were common to both sites (Table 2). Species of oligochaetes, nemerteans, sipunculans, turbellarians, and aplacophorans present in colonization trays at WSS were absent from those at SPR (Table 2). Isopods and gastropods present in trays at SPR were absent at WSS. The number of species observed in trays at WSS was 50\% that of ambient sediments after $7 \mathrm{wk}$ and $59 \%$ of ambient after 6.4 mo (Table 2). At SPR species richness was 17\% that of ambient sediment in $7 \mathrm{wk}$ trays and $34 \%$ of ambient in 6.4 mo trays (Table 2). However, the total tray collections comprised only about half the ambient surface area sampled.

Within-site comparisons of expected species richness revealed no differences between colonizer and ambient assemblages at SPR or WSS (Fig. 5), yet taxonomic differences were striking. Porifera, bryozoans, amphipods, tanaids, holothurians and crinoids were collected in ambient, undisturbed sediments, but were completely absent from the colonization trays. Two polychaete species and 1 sipunculan appeared in colonization trays that were absent in background cores (Table 2)

Over $50 \%$ of the colonists at both sites were polychaetes (WSS, 54 to $58 \%$; SPR, 72 to $84 \%$ ) (Fig. 4). Polychaetes were more common among colonizing infauna than in ambient sediments, where they comprised 42 to $43 \%$ of the infauna at both sites ( $G$-test of treatment effect on polychaete proportion, $p<0.001_{i}$ Sokal \& Rohlf 1981). Dominant polychaete colonists were the hesionid Podarkiopsis sp., unidentified hesionid juveniles, the dorvilleid Protodorvillea sp. C, and unidentified juvenile polychaetes. As a group, dorvilleid and hesionid polychaetes were nearly twice as
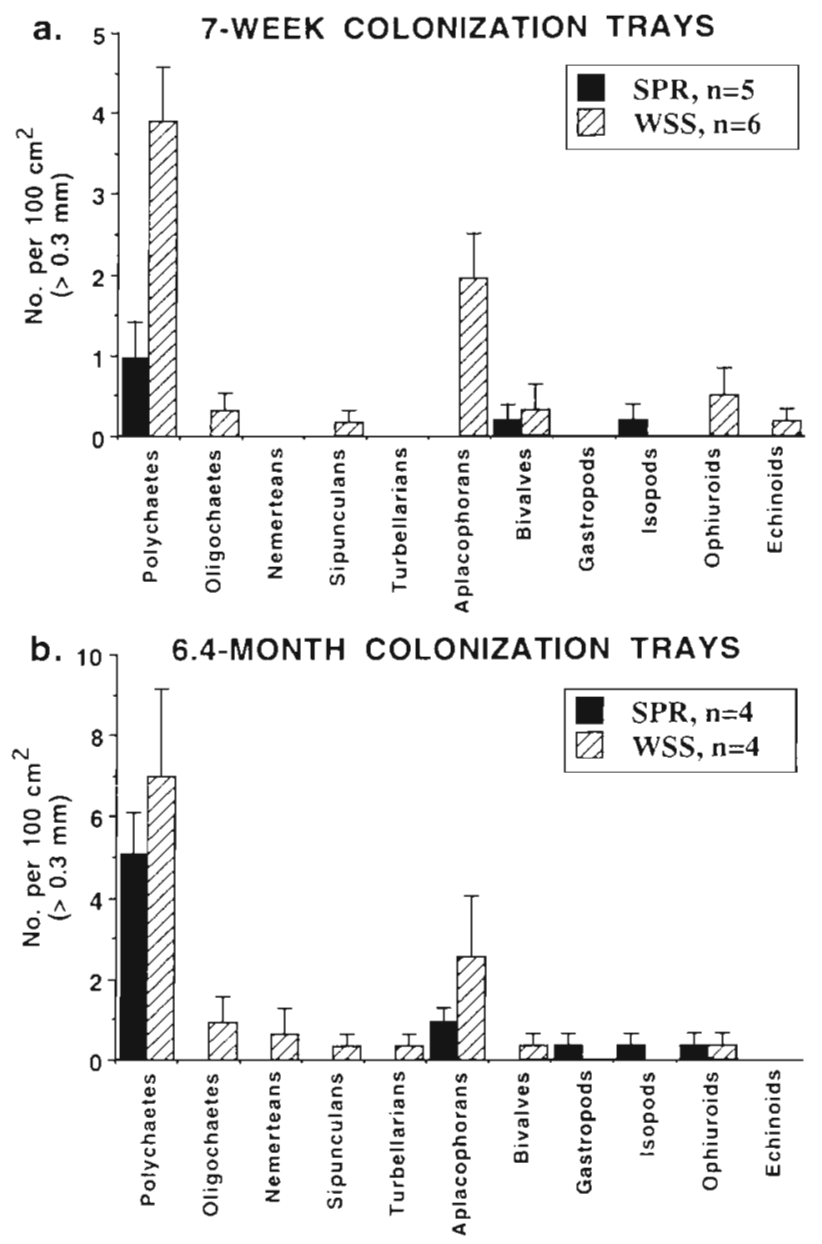

Fig. 4. Densities of major taxa (mean $\left.+1 \mathrm{SE}_{1}>300 \mu \mathrm{m}\right)$ colonizing defaunated sediments after (a) 7 wk and (b) 6.4 mo on Sea Pen Rim (SPR) and White Sand Swale (WSS) atop Fieberling Guyot

common in colonization trays as in ambient sediments, making up 33 and $30 \%$ of macrofaunal colonists in $7 \mathrm{wk}$ and 6.4 mo trays at WSS, respectively, and 50 and $33 \%$ of colonists in $7 \mathrm{wk}$ and 6.4 mo trays at SPR, respectively. In undisturbed sediments these 2 polychaete groups were 15 to $19 \%$ of total macrofauna at WSS, and 3 to $13 \%$ of macrofauna at SPR, depending on collection period. Conspicuously absent from the trays was Synelmis dineti, a pilargid polychaete that comprised $26 \%$ of polychaetes in ambient sediments at SPR and $19 \%$ at WSS. The second most common colonizing taxon, aplacophorans, were present in similar proportions in colonization trays and ambient sediments.

\section{Vertical distributions}

The infauna in the short-term ( $7 \mathrm{wk}$ ) colonization experiments occurred shallower in the sediment trays 
Table 2. Density of macrofaunal taxa $(>0.3 \mathrm{~mm})$ recovered in colonization trays and ambient (control) sediment cores on the summit plain of Fiebering Guyot (no. per $100 \mathrm{~cm}^{2}$ ). Trays were deployed from October 1990 to December 1990 (7.0 wk) or from December 1990 to June 1991 $(6.4 \mathrm{mo})$

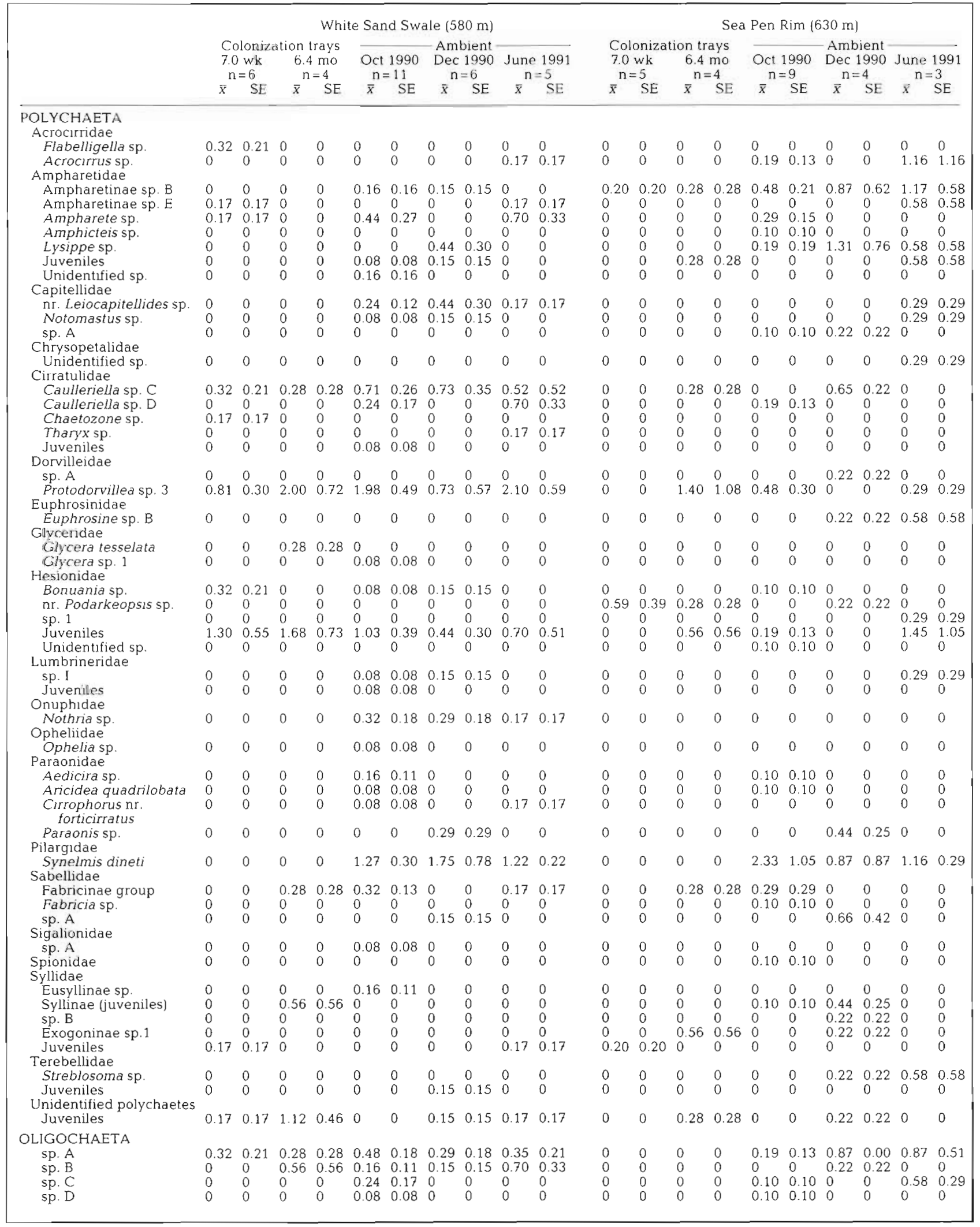


Table 2 (continued)

\begin{tabular}{|c|c|c|c|c|c|c|c|c|c|c|c|c|c|c|c|c|c|c|c|}
\hline & \multicolumn{8}{|c|}{ White Sand Swale (580 m) } & \multicolumn{10}{|c|}{ Sea Pen Rim (630 m) } \\
\hline & & \multicolumn{3}{|c|}{$\begin{array}{ccc}\text { Colonization trays } \\
7.0 \mathrm{wk} & 6.4 \mathrm{mo} \\
\mathrm{n}=6 & \mathrm{n}=4 \\
\bar{x} & \mathrm{SE} & \bar{x}\end{array}$} & $\begin{array}{l}\text { Oct } 1990 \\
\mathrm{n}=11 \\
\bar{x} \quad \mathrm{SE}\end{array}$ & \multicolumn{2}{|c|}{$\begin{array}{c}\text { Ambient } \\
\text { Dec } 1990 \\
\mathrm{n} \equiv 6 \\
\bar{x} \quad \mathrm{SE}\end{array}$} & \multicolumn{2}{|c|}{$\begin{array}{c}\text { June } 1991 \\
n=5 \\
\bar{x} \quad \text { SE }\end{array}$} & \multicolumn{2}{|c|}{$\begin{array}{l}\text { Colonizatio } \\
7.0 \text { wk } \\
n=5 \\
\bar{x}=5\end{array}$} & \multicolumn{2}{|c|}{$\begin{array}{l}100 \text { trays } \\
6.4 \mathrm{mo} \\
\mathrm{n}=4 \\
\bar{x} \quad \mathrm{SE}\end{array}$} & \multicolumn{2}{|c|}{$\begin{array}{l}\text { Odt } 1990 \\
n=9 \\
x \quad S E\end{array}$} & \multicolumn{2}{|c|}{$\begin{array}{l}\text { Ambient } \\
\text { Dec } 1990 \\
n=4 \\
\bar{x} \quad \text { SE }\end{array}$} & \multicolumn{2}{|c|}{$\begin{array}{c}\text { June } 1991 \\
n=3 \\
\bar{x}=3 E\end{array}$} \\
\hline $\begin{array}{l}\text { NEMERTEA } \\
\text { sp. B } \\
\text { sp. C } \\
\text { sp. D } \\
\text { sp. F } \\
\text { sp. G } \\
\text { sp. H } \\
\text { Unidentified }\end{array}$ & $\begin{array}{l}0 \\
0 \\
0 \\
0 \\
0 \\
0 \\
0\end{array}$ & $\begin{array}{l}0 \\
0 \\
0 \\
0 \\
0 \\
0 \\
0\end{array}$ & $\begin{array}{l}0 \\
0.28 \\
0 \\
0.28 \\
0 \\
0 \\
0\end{array}$ & $\begin{array}{l}0 \\
0.28 \\
0 \\
0.28 \\
0 \\
0 \\
0\end{array}$ & $\begin{array}{ll}0.08 & 0.08 \\
0.63 & 0.21 \\
0 & 0 \\
0 & 0 \\
0.08 & 0.08 \\
0.08 & 0.08 \\
0.08 & 0.08\end{array}$ & $\begin{array}{l}0 \\
0.44 \\
0.15 \\
0 \\
0 \\
0 \\
0\end{array}$ & $\begin{array}{l}0 \\
0.19 \\
0.15 \\
0 \\
0 \\
0 \\
0\end{array}$ & $\begin{array}{l}0 \\
0.52 \\
0 \\
0 \\
0 \\
0 \\
0\end{array}$ & $\begin{array}{l}0 \\
0.52 \\
0 \\
0 \\
0 \\
0 \\
0\end{array}$ & $\begin{array}{l}0 \\
0 \\
0 \\
0 \\
0 \\
0 \\
0\end{array}$ & $\begin{array}{l}0 \\
0 \\
0 \\
0 \\
0 \\
0 \\
0\end{array}$ & $\begin{array}{l}0 \\
0 \\
0 \\
0 \\
0 \\
0\end{array}$ & $\begin{array}{l}0 \\
0 \\
0 \\
0 \\
0 \\
0 \\
0 \\
0\end{array}$ & $\begin{array}{ll}0.10 & 0 \\
0 & 0 \\
0 & 0 \\
0.19 & 0 \\
0 & 0 \\
0.10 & 0 \\
0.29 & 0\end{array}$ & $\begin{array}{l}0.10 \\
0 \\
0 \\
0.13 \\
0 \\
0.10 \\
0.21\end{array}$ & $\left.\begin{array}{l}0.44 \\
0 \\
0 \\
0 \\
0 \\
0 \\
0\end{array}\right\}$ & $\begin{array}{l}0.25 \\
0 \\
0 \\
0 \\
0 \\
0 \\
0\end{array}$ & $\begin{array}{l}0.58 \\
0 \\
0 \\
0.58 \\
0 \\
0 \\
0\end{array}$ & $\begin{array}{l}0.29 \\
0 \\
0 \\
0.58 \\
0 \\
0 \\
0\end{array}$ \\
\hline $\begin{array}{l}\text { SIPUNCULA } \\
\text { sp. A (Golfingia) } \\
\text { sp. C } \\
\text { sp. new }\end{array}$ & $\begin{array}{l}0.17 \\
0 \\
0\end{array}$ & $\begin{array}{l}0.17 \\
0 \\
0\end{array}$ & $\begin{array}{l}0 \\
0.28 \\
0\end{array}$ & $\begin{array}{l}0 \\
0.28 \\
0\end{array}$ & $\begin{array}{ll}0.63 & 0.31 \\
0 & 0 \\
0.08 & 0.08\end{array}$ & $\begin{array}{l}1.75 \\
0 \\
0\end{array}$ & $\begin{array}{l}0.55 \\
0 \\
0\end{array}$ & $\begin{array}{l}0.70 \\
0 \\
0\end{array}$ & $\begin{array}{l}0.51 \\
0 \\
0\end{array}$ & $\begin{array}{l}0 \\
0 \\
0 \\
0\end{array}$ & $\begin{array}{l}0 \\
0 \\
0\end{array}$ & $\begin{array}{l}0 \\
0\end{array}$ & $\begin{array}{l}0 \\
0 \\
0\end{array}$ & $\begin{array}{ll}0.39 & 0 \\
0 & 0 \\
0 & 0\end{array}$ & $\begin{array}{l}0.15 \\
0 \\
0\end{array}$ & $\begin{array}{l}0.44 \\
0 \\
0\end{array}$ & $\begin{array}{l}0.25 \\
0 \\
0\end{array}$ & $\begin{array}{l}0.58 \\
0 \\
0\end{array}$ & $\begin{array}{l}0.29 \\
0 \\
0\end{array}$ \\
\hline $\begin{array}{l}\text { TURBELLARIA } \\
\text { sp. } 1 \\
\text { sp. } 2\end{array}$ & $\begin{array}{l}0 \\
0\end{array}$ & $\begin{array}{l}0 \\
0\end{array}$ & $0_{0}^{0.28}$ & $\begin{array}{l}0.28 \\
0\end{array}$ & 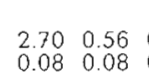 & $\begin{array}{l}0.29 \\
0.73\end{array}$ & $\begin{array}{l}0.29 \\
0.47\end{array}$ & 2.44 & $0_{0}^{1.18}$ & $\begin{array}{l}0 \\
0\end{array}$ & $\begin{array}{l}0 \\
0\end{array}$ & $\begin{array}{l}0 \\
0\end{array}$ & $\begin{array}{l}0 \\
0\end{array}$ & $\begin{array}{l}0.190 \\
0\end{array}$ & $\begin{array}{l}0.19 \\
0\end{array}$ & $\begin{array}{l}0.66 \\
0\end{array}$ & ${ }_{0}^{0.42}$ & $\begin{array}{l}0 \\
0\end{array}$ & $\begin{array}{l}0 \\
0\end{array}$ \\
\hline $\begin{array}{l}\text { PRIAPULIDA } \\
\text { sp. G }\end{array}$ & 0 & 0 & 0 & 0 & 0 & 0 & 0 & 0 & 0 & 0 & 0 & 0 & 0 & 0.100 & 0.10 & 0 & 0 & 0 & 0 \\
\hline $\begin{array}{c}\mathrm{ECH} \\
\mathrm{S}\end{array}$ & 0 & 0 & 0 & 0 & $0.24 \quad 0.17$ & 0 & 0 & 0 & 0 & 0 & 0 & 0 & 0 & 0 & 0 & 0 & 0 & 0 & 0 \\
\hline $\begin{array}{l}\text { UNIDENTIFIED VERME: } \\
\text { sp. H } \\
\text { sp. I } \\
\text { sp. K } \\
\text { Unidentified }\end{array}$ & $\begin{array}{l}0 \\
0 \\
0 \\
0\end{array}$ & $\begin{array}{l}0 \\
0 \\
0 \\
0\end{array}$ & $\begin{array}{l}0 \\
0 \\
0 \\
0\end{array}$ & $\begin{array}{l}0 \\
0 \\
0 \\
0 \\
0\end{array}$ & $\begin{array}{ll}0.16 & 0.16 \\
0 & 0 \\
0 & 0 \\
0 & 0\end{array}$ & $\begin{array}{l}0 \\
0.15 \\
0 \\
0\end{array}$ & $\begin{array}{l}0 \\
0.15 \\
0 \\
0\end{array}$ & $\begin{array}{l}0.17 \\
0 \\
0.17 \\
0\end{array}$ & $\begin{array}{l}0.17 \\
0 \\
0.17 \\
0\end{array}$ & $\begin{array}{l}0 \\
0 \\
0\end{array}$ & $\begin{array}{l}0 \\
0 \\
0 \\
0\end{array}$ & 0 & $\begin{array}{l}0 \\
0 \\
0 \\
0 \\
0\end{array}$ & $\begin{array}{ll}0 & 0 \\
0 & 0 \\
0 & 0 \\
0.48 & 0\end{array}$ & $\begin{array}{l}0 \\
0 \\
0 \\
0.39\end{array}$ & $\begin{array}{l}0 \\
0 \\
0 \\
0 \\
0\end{array}$ & $\begin{array}{l}0 \\
0 \\
0 \\
0 \\
0\end{array}$ & $\begin{array}{l}0 \\
0 \\
0 \\
0\end{array}$ & $\begin{array}{l}0 \\
0 \\
0 \\
0 \\
0\end{array}$ \\
\hline 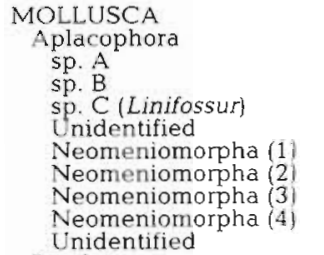 & $\begin{array}{l}0 \\
0.32 \\
0 \\
0 \\
0.66 \\
0 \\
0.81 \\
0 \\
0.17\end{array}$ & $\begin{array}{l}0 \\
2 \\
0.21 \\
0 \\
0 \\
0.48 \\
0 \\
0.39 \\
0 \\
0 \\
0.17\end{array}$ & $\begin{array}{l}0.56 \\
0.28 \\
0 \\
0 \\
0.28 \\
0 \\
0.84 \\
0 \\
0.28\end{array}$ & $\begin{array}{l}0.56 \\
0.28 \\
0 \\
0 \\
0.28 \\
0 \\
0.84 \\
0 \\
0.28\end{array}$ & $\begin{array}{ll}0.48 & 0.48 \\
0.55 & 0.18 \\
0.16 & 0.11 \\
0.71 & 0.37 \\
0 & 0 \\
0 & 0 \\
0.40 & 0.22 \\
0.08 & 0.08 \\
0.64 & 0.34\end{array}$ & $\begin{array}{l}1.46 \\
1.17 \\
0.29 \\
0 \\
0.58 \\
0 \\
0.29 \\
0 \\
0\end{array}$ & $\begin{array}{l}0.66 \\
0.43 \\
0.18 \\
0 \\
0.29 \\
0 \\
0.18 \\
0 \\
0\end{array}$ & $\begin{array}{l}0 \\
0.52 \\
0.17 \\
0 \\
0.70 \\
0 \\
2.10 \\
0.17 \\
0.35\end{array}$ & $\begin{array}{l}0 \\
0.35 \\
0.17 \\
0 \\
0.70 \\
0 \\
1.31 \\
0.17 \\
0.21\end{array}$ & $\begin{array}{l}0 \\
0 \\
0 \\
0 \\
0 \\
0 \\
0 \\
0 \\
0\end{array}$ & $\begin{array}{l}0 \\
0 \\
0 \\
0 \\
0 \\
0 \\
0 \\
0 \\
0\end{array}$ & $\begin{array}{l}0 \\
0 \\
0 \\
0 \\
0.56 \\
0 \\
0.28 \\
0 \\
0\end{array}$ & $\begin{array}{l}0 \\
0 \\
0 \\
0 \\
0.32 \\
0.28 \\
0.28 \\
0 \\
0\end{array}$ & $\begin{array}{ll}0 & 0 \\
0 & 0 \\
0.10 & 0 \\
0.10 & 0 \\
0 & 0 \\
0 & 0 \\
0.10 & 0 \\
0 & 0 \\
0 & 0\end{array}$ & $\begin{array}{l}0 \\
0 \\
0.10 \\
0.10 \\
0 \\
0 \\
0.10 \\
0 \\
0\end{array}$ & $\begin{array}{l}0.44 \\
0.44 \\
0 \\
0 \\
0.22 \\
0 \\
0 \\
0 \\
0.22\end{array}$ & $\begin{array}{l}0.25 \\
0.44 \\
0 \\
0 \\
0.22 \\
0 \\
0 \\
0 \\
0.22\end{array}$ & $\begin{array}{l}0.29 \\
0.29 \\
0 \\
0 \\
0 \\
0.58 \\
0.29 \\
0 \\
0.29\end{array}$ & $\begin{array}{l}0.29 \\
0.29 \\
0 \\
0 \\
0 \\
0.58 \\
0.29 \\
0 \\
0.29\end{array}$ \\
\hline $\begin{array}{l}\text { Bivalvia } \\
\text { sp. A } \\
\text { sp. C } \\
\text { sp. F } \\
\text { sp. G } \\
\text { Cuspidaridae } \\
\text { Unidentified }\end{array}$ & $\begin{array}{l}0 \\
0 \\
0 \\
0.32 \\
0 \\
0\end{array}$ & $\begin{array}{l}0 \\
0 \\
0 \\
0.32 \\
0 \\
0\end{array}$ & $\begin{array}{l}0 \\
0 \\
0.28 \\
0 \\
0 \\
0\end{array}$ & $\begin{array}{l}0 \\
0 \\
0.28 \\
0 \\
0 \\
0\end{array}$ & $\begin{array}{ll}0 & 0 \\
0.63 & 0.27 \\
0.24 & 0.17 \\
0.08 & 0.08 \\
0.24 & 0.17 \\
0 & 0\end{array}$ & $\begin{array}{l}0.15 \\
0.58 \\
0.44 \\
0.29 \\
0.29 \\
0\end{array}$ & $\begin{array}{l}0.15 \\
0.29 \\
0.44 \\
0.29 \\
0.18 \\
0\end{array}$ & $\begin{array}{l}0 \\
0.35 \\
0.70 \\
0.35 \\
0 \\
0\end{array}$ & $\begin{array}{l}0 \\
0.21 \\
0.43 \\
0.35 \\
0 \\
0\end{array}$ & $\begin{array}{l}0 \\
0 \\
0 \\
0.20 \\
0 \\
0\end{array}$ & $\begin{array}{l}0 \\
0 \\
0 \\
0.20 \\
0 \\
0\end{array}$ & $\begin{array}{l}0 \\
0 \\
0 \\
0 \\
0 \\
0.28\end{array}$ & $\begin{array}{l}0 \\
0 \\
0 \\
0 \\
0 \\
0.28\end{array}$ & $\begin{array}{ll}0 & 0 \\
0.10 & 0 \\
0.10 & 0 \\
0 & \\
0.10 & 0 \\
0.10 & \end{array}$ & $\begin{array}{l}0 \\
0.10 \\
0.10 \\
0 \\
0.10 \\
0.10\end{array}$ & $\begin{array}{l}0 \\
0.22 \\
0.44 \\
0 \\
0 \\
0\end{array}$ & $\begin{array}{l}0 \\
0.22 \\
0.44 \\
0 \\
0 \\
0\end{array}$ & $\left.\begin{array}{l}0 \\
0 \\
0 \\
0 \\
0 \\
0 \\
0 \\
0\end{array}\right\}$ & $\begin{array}{l}0 \\
0 \\
0 \\
0 \\
0 \\
0 \\
0\end{array}$ \\
\hline $\begin{array}{l}\text { Gastropoda } \\
\text { sp. } 2 \\
\text { sp. } 3 \\
\text { sp. } 4 \\
\text { Pleurotomella }\end{array}$ & $\begin{array}{l}0 \\
0 \\
0 \\
0 \\
0\end{array}$ & $\begin{array}{l}0 \\
0 \\
0 \\
0\end{array}$ & $\begin{array}{l}0 \\
0 \\
0 \\
0\end{array}$ & $\begin{array}{l}0 \\
0 \\
0 \\
0 \\
0\end{array}$ & $\begin{array}{ll}0 & 0 \\
0 & 0 \\
0.08 & 0.08 \\
0 & 0\end{array}$ & $\begin{array}{l}0 \\
0.15 \\
0 \\
0\end{array}$ & $\begin{array}{l}0 \\
0.15 \\
0 \\
0\end{array}$ & $\begin{array}{l}0 \\
0 \\
0 \\
0 \\
0.17\end{array}$ & $\begin{array}{l}0 \\
0 \\
0 \\
0.1\end{array}$ & $\begin{array}{l}0 \\
0\end{array}$ & $\begin{array}{l}0 \\
0 \\
0 \\
0\end{array}$ & $\begin{array}{l}0 \\
0 \\
0 \\
0 \\
0\end{array}$ & $\begin{array}{l}0 \\
0 \\
0 \\
0 \\
0\end{array}$ & $\begin{array}{l}0 \\
0 \\
0 \\
0\end{array}$ & $\begin{array}{l}0 \\
0 \\
0 \\
0\end{array}$ & $\begin{array}{l}0 \\
0 \\
0 \\
0\end{array}$ & $\begin{array}{l}0 \\
0 \\
0 \\
0 \\
0\end{array}$ & $\begin{array}{l}0.29 \\
0 \\
0 \\
0\end{array}$ & $\begin{array}{l}0.29 \\
0 \\
0 \\
0\end{array}$ \\
\hline $\begin{array}{r}\text { CRUS } \\
\text { Amp } \\
\text { sp. }\end{array}$ & & & & & & & & & 0 & 0 & 0 & 0 & 0 & & & 0 & 0 & & 0 \\
\hline $\begin{array}{r}\text { S1 } \\
\text { Iso } \\
\text { A } \\
\text { A }\end{array}$ & $\begin{array}{l}0 \\
0 \\
0\end{array}$ & $\begin{array}{l}0 \\
0 \\
0 \\
0\end{array}$ & $\begin{array}{l}0 \\
0 \\
0 \\
0\end{array}$ & $\begin{array}{l}0 \\
0 \\
0 \\
0\end{array}$ & $\begin{array}{ll}0.08 & 0.08 \\
0 & 0 \\
0.24 & 0.12 \\
0.08 & 0.08\end{array}$ & $\begin{array}{l}0 \\
0 \\
0 \\
0\end{array}$ & $\begin{array}{l}0 \\
0 \\
0 \\
0\end{array}$ & $\begin{array}{l}0 \\
0 \\
0 \\
0\end{array}$ & $\begin{array}{l}0 \\
0 \\
0\end{array}$ & $\begin{array}{l}0 \\
0 \\
0.20 \\
0\end{array}$ & $\begin{array}{l}0 \\
0.20 \\
0\end{array}$ & $\begin{array}{l}0 \\
0.28 \\
0\end{array}$ & $\begin{array}{l}0 \\
0.28 \\
0\end{array}$ & $\begin{array}{ll}0 & 0 \\
0.49 & 0 \\
0.10 & 0\end{array}$ & $\begin{array}{l}0.11 \\
0 \\
0.26 \\
0.10\end{array}$ & $\begin{array}{l}0.44 \\
0 \\
0\end{array}$ & $\begin{array}{l}0.25 \\
0 \\
0\end{array}$ & $\begin{array}{l}0.87 \\
0.29 \\
0\end{array}$ & $\begin{array}{l}0.51 \\
0.29 \\
0\end{array}$ \\
\hline $\begin{array}{r}\text { Tandi } \\
\text { Lept } \\
\text { sp. }\end{array}$ & $\begin{array}{l}0 \\
0\end{array}$ & $\begin{array}{l}0 \\
0\end{array}$ & $\begin{array}{l}0 \\
0\end{array}$ & $\begin{array}{l}0 \\
0\end{array}$ & $\begin{array}{ll}0 & 0 \\
0 & 0\end{array}$ & $\begin{array}{l}0 \\
0.15\end{array}$ & $\begin{array}{l}0 \\
0.15\end{array}$ & $\begin{array}{l}0 \\
0\end{array}$ & $\begin{array}{l}0 \\
0\end{array}$ & $\begin{array}{l}0 \\
0\end{array}$ & $\begin{array}{l}0 \\
0\end{array}$ & $\begin{array}{l}0 \\
0\end{array}$ & $\begin{array}{l}0 \\
0\end{array}$ & $\begin{array}{ll}0.39 & 0 \\
0 & 0\end{array}$ & $\begin{array}{l}0.30 \\
0\end{array}$ & $\begin{array}{l}0 \\
0.66\end{array}$ & $\begin{array}{l}0 \\
0.42\end{array}$ & $\begin{array}{l}0 \\
0\end{array}$ & $\begin{array}{l}0 \\
0 \\
0\end{array}$ \\
\hline $\begin{array}{l}\text { ECHINODERMA } \\
\text { Holothurian } \\
\text { sp. A } \\
\text { sp. B } \\
\text { sp. C } \\
\text { Unidentified }\end{array}$ & $\begin{array}{l}0 \\
0 \\
0 \\
0 \\
0\end{array}$ & $\begin{array}{l}0 \\
0 \\
0 \\
0\end{array}$ & $\begin{array}{l}0 \\
0 \\
0 \\
0\end{array}$ & $\begin{array}{l}0 \\
0 \\
0 \\
0 \\
0\end{array}$ & $\begin{array}{ll}0 & 0 \\
0 & 0 \\
0.24 & 0.24 \\
0 & 0\end{array}$ & $\begin{array}{l}0.15 \\
0.15 \\
0 \\
0\end{array}$ & $\begin{array}{l}0.15 \\
0.15 \\
0 \\
0\end{array}$ & $\begin{array}{l}0 \\
0.17 \\
0 \\
0\end{array}$ & $\begin{array}{l}0 \\
0.17 \\
0 \\
0\end{array}$ & $\begin{array}{l}0 \\
0 \\
0 \\
0\end{array}$ & $\begin{array}{l}0 \\
0 \\
0 \\
0\end{array}$ & $\begin{array}{l}0 \\
0 \\
0 \\
0\end{array}$ & $\begin{array}{l}0 \\
0 \\
0 \\
0 \\
0\end{array}$ & $\begin{array}{l}0.190 \\
0 \\
0.100\end{array}$ & $\begin{array}{l}0 \\
0.13 \\
0 \\
0.10\end{array}$ & $\begin{array}{l}0 \\
0 \\
0 \\
0 \\
0\end{array}$ & $\begin{array}{l}0 \\
0 \\
0 \\
0\end{array}$ & $\begin{array}{l}0 \\
0 \\
0 \\
0\end{array}$ & $\begin{array}{l}0 \\
0 \\
0 \\
0\end{array}$ \\
\hline $\begin{array}{l}\text { sp. G } \\
\text { sp. H } \\
\text { sp. I } \\
\text { Urchin sp. } \\
\text { Crinoid sp. }\end{array}$ & $\begin{array}{l}0 \\
0 \\
0.49 \\
0.17 \\
0\end{array}$ & $\begin{array}{l}0 \\
0 \\
0.33 \\
0.17 \\
0\end{array}$ & $\begin{array}{l}0 \\
0 \\
0.28 \\
0 \\
0\end{array}$ & $\begin{array}{l}0 \\
0 \\
0.28 \\
0 \\
0\end{array}$ & $\begin{array}{ll}0 & 0 \\
0 & 0 \\
0.24 & 0.17 \\
0 & 0 \\
0 & 0\end{array}$ & $\begin{array}{l}0 \\
0 \\
0 \\
0.15 \\
0\end{array}$ & $\begin{array}{l}0 \\
0 \\
0 \\
0.15 \\
0\end{array}$ & $\begin{array}{l}0.17 \\
0 \\
0.17 \\
0 \\
0\end{array}$ & $\begin{array}{l}0.17 \\
0 \\
0.17 \\
0 \\
0\end{array}$ & $\begin{array}{l}0 \\
0 \\
0 \\
0 \\
0 \\
0\end{array}$ & $\begin{array}{l}0 \\
0 \\
0 \\
0 \\
0\end{array}$ & $\begin{array}{l}0.28 \\
0 \\
0 \\
0 \\
0\end{array}$ & $\begin{array}{l}0.28 \\
0 \\
0 \\
0 \\
0\end{array}$ & $\begin{array}{ll}0 & 0 \\
0.78 & 0 \\
0 & 0 \\
0 & 0 \\
0.78 & 0\end{array}$ & $\begin{array}{l}0 \\
0.49 \\
0 \\
0 \\
0.53\end{array}$ & $\left.\begin{array}{l}0.87 \\
0 \\
0 \\
0.44 \\
0.44\end{array}\right\}$ & $\begin{array}{l}0.00 \\
0 \\
0 \\
0.25 \\
0.25\end{array}$ & $\begin{array}{l}0.29 \\
0 \\
0 \\
0 \\
0.87\end{array}$ & $\begin{array}{l}0.29 \\
0 \\
0 \\
0 \\
0.87\end{array}$ \\
\hline $\begin{array}{l}\text { OTHER } \\
\text { POrife } \\
\text { Coele } \\
\text { Anem } \\
\text { Bryoz } \\
\text { Pycno } \\
\text { Acarir } \\
\text { Chaet }\end{array}$ & $\begin{array}{l}0 \\
0 \\
0 \\
0 \\
0 \\
0 \\
0 \\
0\end{array}$ & $\begin{array}{l}0 \\
0 \\
0 \\
0 \\
0 \\
0 \\
0\end{array}$ & $\begin{array}{l}0 \\
0 \\
0 \\
0 \\
0 \\
0 \\
0\end{array}$ & $\begin{array}{l}0 \\
0 \\
0 \\
0 \\
0 \\
0 \\
0\end{array}$ & $\begin{array}{lll}0.40 & 0.18 & \\
0.08 & 0.08 & \\
0.55 & 0.18 & \\
0 & 0 & \\
0 & 0 & \\
0.08 & 0.08 & \\
0.16 & 0.11\end{array}$ & $\begin{array}{l}0.15 \\
0 \\
0 \\
0 \\
0 \\
0 \\
0\end{array}$ & $\begin{array}{l}0.15 \\
0 \\
0 \\
0 \\
0 \\
0 \\
0\end{array}$ & $\begin{array}{l}0 \\
0 \\
0 \\
0 \\
0 \\
0 \\
0\end{array}$ & $\begin{array}{l}0 \\
0 \\
0 \\
0 \\
0 \\
0 \\
0\end{array}$ & $\begin{array}{l}0 \\
0 \\
0 \\
0 \\
0 \\
0 \\
0\end{array}$ & $\begin{array}{l}0 \\
0 \\
0 \\
0 \\
0 \\
0 \\
0\end{array}$ & $\begin{array}{l}0 \\
0 \\
0 \\
0 \\
0 \\
0 \\
0 \\
0\end{array}$ & $\begin{array}{l}0 \\
0 \\
0 \\
0 \\
0 \\
0 \\
0 \\
0\end{array}$ & $\begin{array}{ll}0.10 & 0 \\
0.58 & 0 \\
0.29 & 0 \\
0.10 & 0 \\
0 & 0 \\
0 & 0\end{array}$ & $\begin{array}{l}0.30 \\
0.10 \\
0.48 \\
0.15 \\
0.10 \\
0 \\
0\end{array}$ & $\begin{array}{l}0.44 \\
0 \\
0.44 \\
0.44 \\
0 \\
0 \\
0\end{array}$ & $\begin{array}{l}0.44 \\
0.44 \\
0.44 \\
0.44 \\
0 \\
0 \\
0\end{array}$ & $\begin{array}{l}1.46 \\
0 \\
0 \\
0 \\
0 \\
0 \\
0 \\
0\end{array}$ & $\begin{array}{l}0.77 \\
0 \\
0 \\
0 \\
0 \\
0 \\
0\end{array}$ \\
\hline $\begin{array}{l}\text { Minimum no of species } \\
\text { Total no of individuals }\end{array}$ & $\begin{array}{l}19 \\
45\end{array}$ & & $\begin{array}{l}20 \\
39\end{array}$ & & $\begin{array}{r}53 \\
255\end{array}$ & $\begin{array}{r}38 \\
114\end{array}$ & & $\begin{array}{r}34 \\
107\end{array}$ & & & & $\begin{array}{l}14 \\
22\end{array}$ & & $\begin{array}{r}43 \\
132\end{array}$ & & $\begin{array}{l}30 \\
72\end{array}$ & & $\begin{array}{l}27 \\
64\end{array}$ & \\
\hline
\end{tabular}



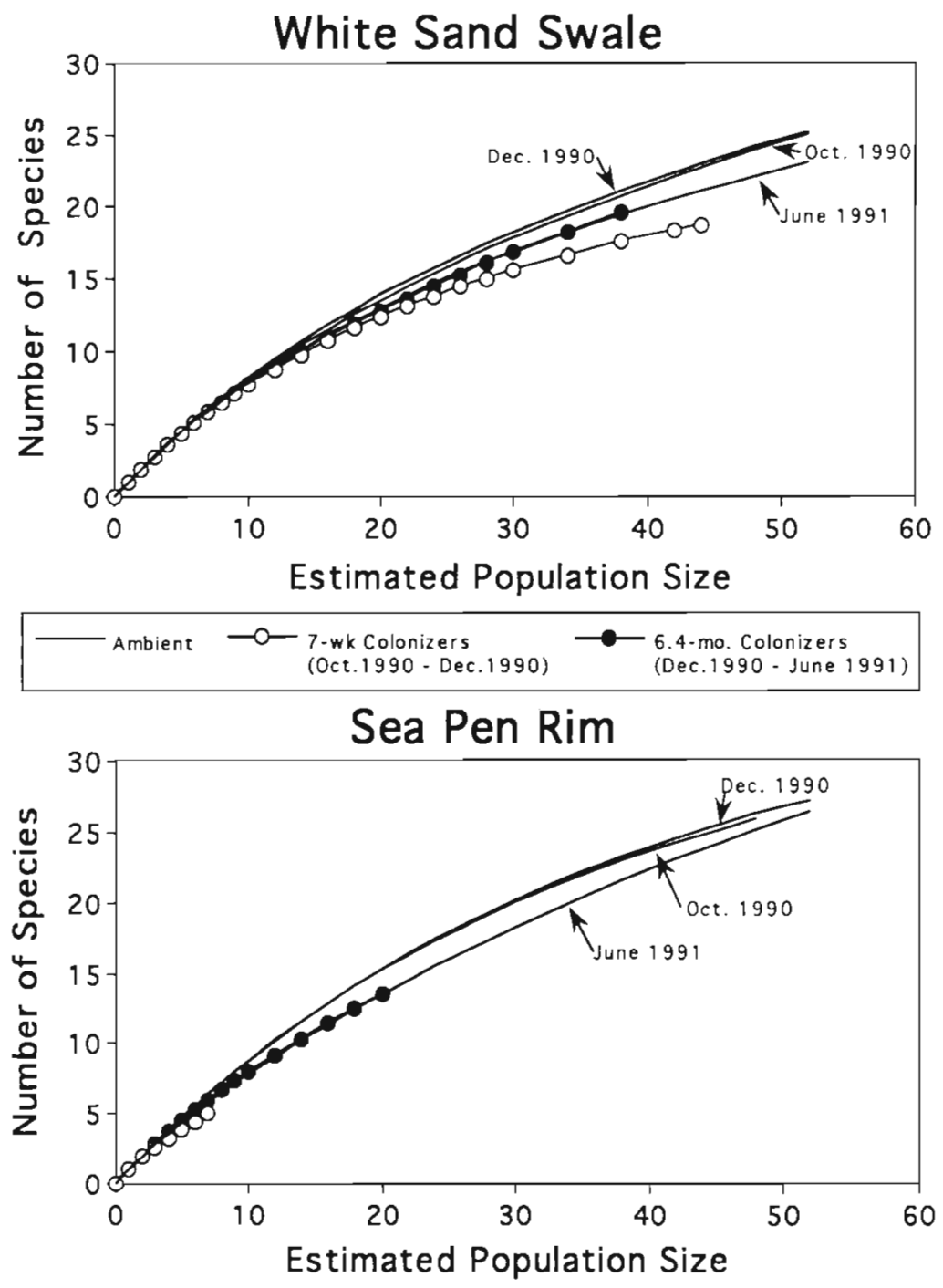

Fig. 5. Rarefaction curves for infaunal assemblages $(>300 \mu \mathrm{m})$ recovered in colonization trays deployed for 7 wk (open symbols) and 6.4 mo (filled symbols) and in ambient sediments (lines without symbols) collected 3 times in 1 yr at White Sand Swale (WSS, $580 \mathrm{~m}$ ) and Sea Pen Rim (SPR, $635 \mathrm{~m}$ ) on the summit plain atop Fieberling Guyot
Life habits

In the 7 wk colonization trays, carnivores were poorly represented relative to ambient sediment (tray vs ambient sediments: $p=0.067$ at WSS; $p=<0.001$ at $\mathrm{SPR})$ as were filter feeders at SPR ( $\mathrm{p}<$ $0.001 \mathrm{j}$. After $6.4 \mathrm{mo}$, the relative proportions of different colonizer feeding types were more similar to those of ambient sediments (Fig. 6a). At WSS, subsurface deposit feeders were more common in colonization trays than in ambient sediments (at 7 wk, p =0.009; at $6.4 \mathrm{mo}, \mathrm{p}=$ 0.051 ) and a similar, but non-significant trend was apparent at SPR (Fig. 6a). Sessile taxa, in particular, were slow to colonize the trays. About $28 \%$ of the fauna in ambient SPR sediments were sessile forms, but animals with this lifestyle were absent in the $7 \mathrm{wk}$ colonization trays ( 7 wk tray vs ambient sediments at SPR, $p=0.036$ ) (Fig. 6b). At WSS sessile lifestyles were equally represented in ambient sediments, $7 \mathrm{wk}$ colonization trays and 6.4 mo trays; about $3 \%$ of the fauna exhibited this lifestyle (Fig. 6b).

Between-site differences among colonizer life habits reflected those in undisturbed sediments (Fig. 6a, b; Levin et al. 1994a). For example, in the 6.4 mo trays, surface deposit feeding (SDF) colonizers were more common at SPR than WSS (proportion SDF at SPR vs WSS, p = 0.004), as were sessile species (proportion sessile at SPR vs WSS, $p=0.003$ ), while motile species were more common at WSS than SPR (proportion mobile at SPR vs WSS, $p=0.052$ ) (Fig. 6a, b).

\section{DISCUSSION}

than in ambient sediments. At SPR, the top $1 \mathrm{~cm}$ contained $75 \pm 25 \%$ of infauna in the colonization trays, compared to $53 \pm 7 \%$ in ambient sediments. At WSS, the top $1 \mathrm{~cm}$ contained $46 \pm 10 \%$ of the infauna in colonization trays, compared with $30 \pm 3.1 \%$ in ambient sediments. The tendency for colonizers to dwell shallower at SPR than WSS mirrored trends observed in undisturbed sediments (Levin et al. 1994a). The 6.4 mo colonization experiments did not exhibit differences in macrofaunal vertical distribution between sites or treatments (trays vs ambient conditions). In the 6.4 mo trays, the top $1 \mathrm{~cm}$ contained $46 \pm 19 \%$ of the animals at SPR and $41 \pm 12 \%$ at WSS.

\section{Colonization rates and community response to disturbance}

Community recovery rates observed on Fieberling Guyot were generally slower than those observed after similar disturbances in shallow subtidal sands and sandflats, where recovery of total macrofaunal densities occurs in a few days to a few weeks (e.g. Van Blaricom 1982, Savidge \& Taghon 1988, Smith \& Brumsickle 1989, Hall 1994). However, recovery times on Fieberling Guyot, especially those at WSS, were shorter than those reported for other unenriched, 


\section{a. Feeding Mode}
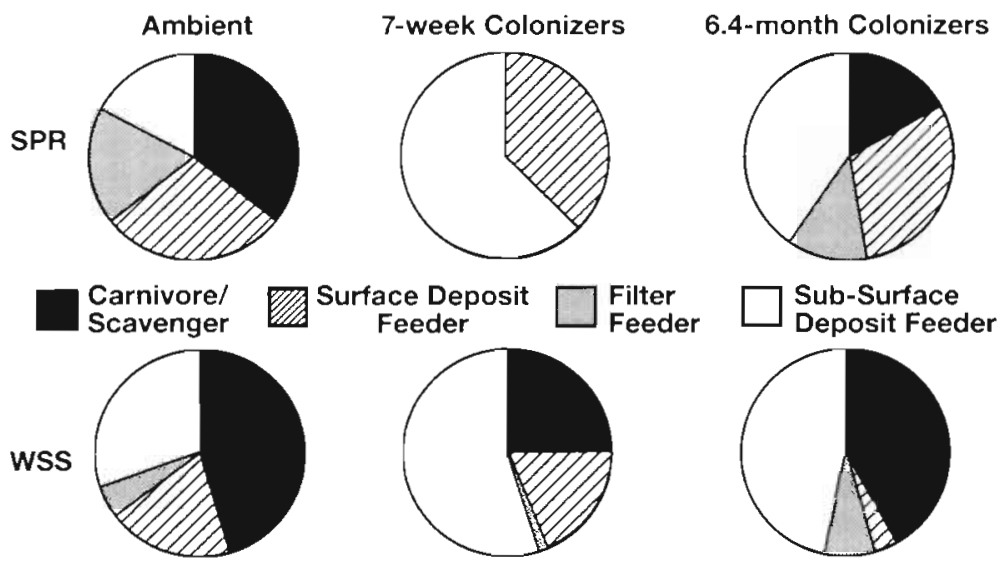

\section{b. Motility}
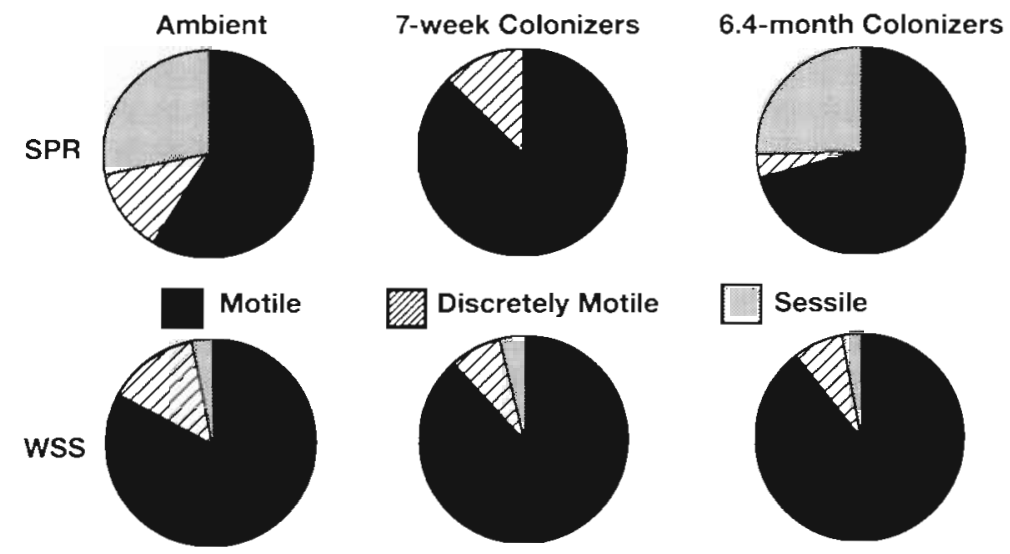

Fig. 6. Life habits of infauna (>300 $\mathrm{\mu m}$ ) colonizing sediment trays exposed for $7 \mathrm{wk}$ and $6.4 \mathrm{mo}$, and those in ambient (undisturbed) sediments at Sea Pen Rim (SPR) and White Sand Swale (WSS) atop the summit plain of Fieberling Guyot. (a) Feeding modes. (b) Motility patterns

deep-sea settings (reviewed in Table 1 of Smith 1994), where defaunated sediments may require years to attain ambient infaunal densities. Macrofauna colonizing defaunated sediments at WSS attained densities statistically indistinguishable from ambient levels in 6.4 mo (or less). At SPR colonizer densities were only half of ambient levels after this period.

Colonization studies were carried out by Snelgrove et al. (1992, 1994, unpubl.) using identical trays at 900 $\mathrm{m}$ water depth near St. Croix, U.S. Virgin Islands. Their study area had mixed coarse and fine carbonate sediment and similar ambient macrofaunal densities (1800 to $1900 \mathrm{~m}^{-2}$ ) to those on Fieberling Guyot, but weaker currents $\left(<5 \mathrm{~cm} \mathrm{~s}^{-1}\right)$ and no evidence of sediment transport. Snelgrove et al. (1992, unpubl.) report that unenriched, defaunated sediments in trays contained macrofaunal densities $28 \%$ of ambient after $23 \mathrm{~d}$, and $608 \%$ of ambient after 29 mo. Diversity in Snelgrove et al.'s 23 d colonization trays did not differ from ambient. Their short-term studies indicate colonization rates comparable to those we observed at WSS $31 \%$ recovery in $7 \mathrm{wk}$ ).

The density overshoot reported by Snelgrove et al. (unpubl.) for the long-term trays is a phenomenon also reported by Desbruyères et al. (1980), who obtained densities $500 \%$ of background levels after $6 \mathrm{mo}$ in the Bay of Biscay at $2160 \mathrm{~m}$. In both of these studies enrichment opportunists rare in background sediments (spionid, dorvilleid, and capitellid polychaetes) were at least partly responsible for the overabundance. Excess organic matter was present close to or in the experimental trays in both these cases. In Snelgrove et al.'s study, algal-enriched trays were placed nearby while in Desbruyère et al.'s, organic matter may have been trapped within the trays (Desbruyères et al. 1985).

Grassle (1977) observed 10\% recovery for macrofauna in defaunated sediments within trays atop the seafloor at $1800 \mathrm{~m}$ in the NW Atlantic after 26 mo. He noted that $70 \%$ of the colonizing species were not present in background cores. Other experiments in surface trays and seafloor patches involving defaunated and organically enriched sediments also resulted in colonization largely by species rare in the background community (Grassle \& MorsePorteous 1987).

These results contrast with our Fieberling Guyot experiments, in which $91 \%$ of the species and $95 \%$ of the individuals colonizing trays were taxa also present in background sediments. The isolation afforded to the summit habitats by the 3.8 -km-high seamount may reduce availability of outside colonizers. The prevalence of background fauna as early colonizers, combined with low diversity of the ambient infauna relative to other deepwater settings (Fig. 5, Shannon-Wiener Index $H^{\prime}=3.44$ at WSS, $H^{\prime}=3.57$ at SPR; Levin et al. $1994 \mathrm{a}$ ), suggests that the Fieberling Guyot sediments are chronically disturbed. Frequent disturbance from daily ripple migration occurs at WSS. At SPR the presence of older bedforms that are $5 \mathrm{~m}$ wavelength (Levin et al. 1994a) indicate that much less frequent, but potentially significant sediment transport can occur at this site. Colonization of defaunated substrates by background species has been observed in the Santa Catalina Basin where disturbance by echiuran fecal mound deposition is common (Levin \& Smith 1984, Kukert \& Smith 1992). 
The frequent occurrence of hesionid and dorvilleid polychaetes on Fieberling Guyot (Table 2) may be indicative of disturbed regimes. These same groups are reported to colonize azoic trays and decomposing seaweed patches in NW Atlantic muds (Grassle 1977. Grassle \& Morse-Porteous 1987). Several dorvilleids dominate oily hydrothermal sediments at $2700 \mathrm{~m}$ in the Guaymas Basin, Gulf of California, Mexico (Grassle et al. 1985). Atop Volcano 7 in the eastern tropical Pacific, 1 hesionid and 1 dorvilleid species together account for $45 \%$ of the polychaetes inhabiting a foraminiferal sand habitat within the oxygen minimum zone (Levin et al. 1991). Thus, members of these 2 polychaete families appear well adapted to stressed settings in both muds and sands of the deep sea.

\section{Colonization mechanisms}

Several modes of colonization are possible: recruitment by planktonic larvae, active migration by juveniles and adults, or passive transport and deposition into the trays of all life stages. The last of these was expected to prevail at WSS, the first and second at SPR. We observed no evidence of colonization predominantly by larvae at either site; adult individuals were present in $7 \mathrm{wk}$ and 6.4 mo trays at both sites (Levin \& DiBacco unpubl. obs.). Active migration of postlarval stages laterally or upward through the sediment, a dominant colonization mechanism in shallow and deep water (Wilson 1981, Levin 1984, Smith \& Brumsickle 1989, Kukert \& Smith 1992), was unlikely due to the broad collar and mesh net of the colonization tray, except at WSS where sediments migrating over the collar may come into contact with defaunated substrates. Passive advection of juvenile polychaetes, bivalves and meiofaunal taxa is well documented in shallow, high-energy sites (e.g. Palmer 1988, Savidge \& Taghon 1988, Emerson \& Grant 1991), but is not widely known from deep water (see Thistle 1988). Smith \& Brumsickle (1989) observed that postlarval migration was more important in smaller $\left(50 \mathrm{~cm}^{2}\right)$ than larger $\left(1750 \mathrm{~cm}^{2}\right)$ patches on a tidal sandflat. Thus, we are reluctant to generalize from our tray experiments to colonization mechanisms in large-scale disturbances on seamounts.

The presence of numerous juvenile polychaetes at both sites indicates some recruitment of larvae or very young postlarval stages. At WSS almost half the polychaetes collected in colonization trays were juveniles, and at SPR about 25\% were juveniles (Table $2 ; 7$ wk and 6.4 mo trays). Polychaetes in ambient sediments were 13 to $15 \%$ juveniles at WSS and 9 to $21 \%$ at SPR (Table 2; October 1990, December 1990 and June 1990). Plankton tows made near our study sites con- tained several taxa found in colonization trays, including postlarval hesionid and syllid polychaetes, postlarval aplacophorans, and hesionid larvae (L. Mullineaux pers. comm.). Differences in taxonomic composition between colonizers at WSS and SPR suggest that the source pool of colonizers is either highly localized (over 100s of $\mathrm{m}$ ), exhibits strong habitat selection or experiences differential post-settlement mortality. Brooded larvae in pouches or tubes have been observed for some of our specimens from ambient Fieberling sediments (e.g. Protodorvillea sp. 3, Caulleriella sp. C) and are reported to occur for other polychaete taxa colonizing the trays (e.g. Ampharete, fabricinids, exogonids) (Wilson 1991, Levin et al. 1994b). Brooded larvae are released at relatively late stages and often experience more limited dispersal than non-brooded forms, though strong bottom currents on Fieberling Guyot could transport larvae more than $1 \mathrm{~km}$ in an hour.

Among 7 wk colonizers, deposit feeding (surface and subsurface) was the dominant feeding mode (Fig. 6a) and most individuals were mobile forms (Fig. 6b). Sessile filter feeders and carnivores were much slower to appear. Lifestyles of colonizers in the $7 \mathrm{wk}$ trays at both WSS and SPR were similar to those of the ambient WSS assemblage (Fig. 6). However, after $6.4 \mathrm{mo}$, colonizer feeding modes and motility patterns at SPR resembled those in the ambient SPR assemblage (Fig. 6). Our interpretation is that the natural condition at WSS is disturbed and the ambient fauna retains features of early succession, similar to those seen in colonization trays after 7 wk at WSS and SPR. Daily ripple migration and high rattail feeding activity are possible sources of disturbance. Similar interpretations have been made for a tidal flat fauna that rapidly colonized simulated ray pit disturbances (Levin 1984) and for the deepwater High Energy Benthic Boundary Layer (HEBBLE) fauna that is subject to extensive sediment erosion and deposition events (Thistle et al. 1985).

The lack of replicate study sites with frequent and infrequent sediment transport prevents us from drawing definitive conclusions about the relationship between substrate motion and community response to disturbance. However, our results indicate that infaunal assemblages of sediments experiencing regular (e.g. daily) transport (1) recover from small-scale disturbance more quickly than those in stable substrates, but (2) probably also retain many 'early successional' characteristics.

Acknowledgements. We thank C. Huggett for invaluable assistance during the field and laboratory phases of this research. The efforts of the captain, crews, and A.LVIN pilots as well as many cruise participants are greatly appreciated; without them these experiments could not have been carried out. We also thank P. Snelgrove for generously sharing his 
colonization tray design and $\mathrm{D}$. Thistle for loaning us several boxcores. G. Gibson, P. Snelgrove and an anonymous reviewer provided helpful comments on the manuscript. This research was supported by ONR grants N00014-89-J-3072 and N00014-92-J-1857 to L.A.L.

\section{LITERATURE CITED}

Bertram MA, Cowen JP (1994) Testate rhizopod growth and mineral deposition of experimental substrate from Cross Seamount. Deep Sea Res 41:575-601

Brink KH (1990) On the generation of seamount trapped waves. Deep Sea Res 37:1569-1582

Desbruyères D, Bervas JY, Khripounoff A (1980) Un cas de recolonization rapide d'un sédiment profond. Oceanol Acta 3:285-291

Desbruyères D, Deming W, Dinet A, Khripounoff A (1985) Reactions de l'ecosysteme benthique profond aux perturbations: nouveaux resultats experimentaux. In: Laubier L, Monier CI (eds) Peuplements profonds du golfe de Gascogne. IFREMER, Brest, p 193-208

Emerson CW, Grant J (1991) The control of soft-shell clam. (Mya arenaria) recruitment on intertidal sandflats by bedload sediment transport. Limnol Oceanogr 36:1288-1300

Eriksen CC (1991) Observations of amplified flows atop a large seamount. J geophys Res Oceans 96:15227-15236

Genin A, Noble M, Lonsdale PF (1989) Tidal currents and anticyclonic motions on two North Pacific Seamounts. Deep Sea Res 36:1803-1816

Giller PS, Hildrew AG, Raffaelli DG (1994) Aquatic ecology: scale, pattern and process. Blackwell Scientific Publications, Oxford

Grassle JF (1977) Slow recolonization of deep-sea sediment Nature 265:618-61.9

Grassle JF, Brown-Leger S, Morse-Porteous L, Petrecca R, Williams I (1985) Deep-sea fauna of sediments in the vicinity of hydrothermal vents. Bull Biol Soc Wash 6: $443-452$

Grassle JF, Grassle JP (1994) Notes from the abyss: the effects of a patchy supply of organic material and larvae on soft-sediment benthic communities. In: Giller PS, Hildrew AG, Raffaelli DG (eds) Aquatic ecology: scale, pattern and process. Blackwell Scientific Publications, Oxford, p 499-516

Grassle JF, Morse-Porteous LS (1987) Macrofaunal colonization of disturbed deep-sea environments and the structure of deep-sea benthic communities. Deep Sea Res 34 $1911-1950$

Hall SF (1994) Physical disturbance and marine benthic communities: life in unconsolidated sediments. Oceanogr mar Biol A Rev 32:179-2.39

Hurlbert SH (1971) The nonconcept of species diversity: a critique and alternative parameters. Ecology 52:577-586

Kaufmann RS, Wakefield WW, Genin A (1989) Distribution of epibenthic megafauna and lebensspuren on two central North Pacific seamounts. Deep Sea Res 36:1863-1896

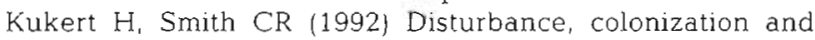
succession in a deep-sea sediment community: artificial mound-experiments. Deep Sea Res 39:1349-1371

Levin LA (1984) Life history and dispersal patterns in a dense infaunal polychaete assemblage: community structure and response to disturbance. Ecology 65:1185-1200

Levin LA, Huggett CL, Wishner KF (1991) Control of deep-sea benthic community structure by oxygen and organicmatter gradients in the eastern Pacific Ocean. J mar Res 49:763-800
Levin LA, Leithold EL, Gross TF, Huggett CL, DiBacco C (1994a) Contrasting effects of substrate mobility on infaunal assemblages inhabiting two high-energy settings on Fieberling Guyot. J mar Res 52:489-522

Levin LA, Nittrouer CA (1987) Textural characteristics of sediments on deep seamounts in the eastern Pacific Ocean between $10^{\circ} \mathrm{N}$ and $30^{\circ} \mathrm{N}$. In: Keating B, Fryer P, Batiza R, Boehlert $G$ (eds) Seamounts, islands and atolls. Geophys Monogr No 43 American Geophysical Union, Washington, DC, p 187-203

Levin LA, Plaia GR, Huggett CL (1994b) The influence of natural organic enhancement on life histories and community structure of bathyal polychaetes. In: Young $\mathrm{CM}$, Eckelbarger KE (eds) Invertebrate reproduction, larval biology and recruitment in the deep sea benthos. Columbia University Press, New York, p 261-283

Levin LA, Smith CR (1984) Response of background fauna to disturbance and enrichment in the deep sea: a sediment tray experiment. Deep Sea Res 31:1277-1285

Mullineaux LS, Butman CA (1990) Recruitment of encrusting benthic invertebrates in boundary layer flows: a deepwater experiment on Cross Seamount. Limnol Oceanogr 35:409-423

Noble M, Cacchıone DA, Schwab WC (1988) Observations of strong mid-Pacific internal tides above Horizon Guyot. J phys Oceanogr 18:1300-1306

Noble M. Mullineaux LS (1989) Internal tidal currents over the summit of Cross Seamount. Deep Sea Res 336: $1791-1802$

Palmer MA (1988) Dispersal of marine meiofauna: a review and conceptual model explaining passive transport and active emergence with implications for recruitment. Mar Ecol Prog Ser 48:81-91

Pickett STA, White PS (eds) (1985) The ecology of natural disturbance and patch dynamics. Academic Press, Orlando

Reimers CE, Wakefield WW (1989) Flocculation of siliceous detritus on the sea floor of a deep Pacific seamount. Deep Sea Res 36:1841-1862

Rhoads DC, Boyer LF (1982) The effects of marine benthos on physical properties of sediments: a successional perspective. In: McCall PL, Tevesz MJS (eds) Animal-sediment relations. Plenum Press, New York, p 3-52

Rice AL, Lambshead PJD (1994) Patch dynamics in the deepsea benthos: the role of a heterogenous supply of organic matter. In: Giller PS, Hildrew AG, Raffaelli DG (eds) Aquatic ecology: scale, pattern and process. Blackwell Scientific Publications, Oxford, p 469-497

Roden G (1987) Effects of seamounts and seamount chains on ocean circulation and thermohaline structure. In: Keating B, Fryer P, Batiza R, Boehlert G (eds) Seamounts, islands and atolls. Geophys Monogr No 43 American Geophysical Union, Washington, DC, p 335-354

Savidge WB, Taghon GL (1988) Passive and active components of colonization following two types of disturbance on intertidal sandflat. J exp mar Biol Ecol 115:137-155

Smith CR (1985) Colonization studies in the deep sea: are results biased by experimental designs? In: Gibbs PE (ed) proceedings of the Nineteenth European Marine Biology Symposium. Cambridge University Press, Cambridge, p $183-190$

Smith CR (1994) Tempo and mode in deep-sea benthic ecology: punctuated equilibrium revisited Palaios 9:3-13

Smith CR, Brumsickle SJ (1989) The effects of patch size and substrate isolation on colonization modes and rates in an intertidal sediment. Limnol Oceanogr 34:1263-1277

Smith CR, Hessler RR (1987) Colonization and succession in deep-sea ecosystems. Trends Ecol Evol 2:359-363 
Snelgrove PVR (1993) The importance of fine-scale flow processes and food availability in the maintenance of soft sediment communities. WHOI 93-27 PhD thesis, Woods Hole Oceanographic Institution, Woods Hole

Snelgrove PVR (1994) Hydrodynamic enhancement of invertebrate larval settlement in microdepositional environments: colonization tray experiments in a muddy habitat. J exp mar Biol Ecol 176:149-166

Snelgrove PVR, Grassle JF, Petrecca RF (1992) The role of food patches in maintaining high deep-sea diversity: field experiments with hydrodynamically unbiased colonization trays. Limnol Oceanogr 37:1543-1550

Snelgrove PVR, Grassle JF, Petrecca RF (1994) Macrofaunal response to artificial enrichments and depressions in a deep-sea habitat. J mar Res 52:345-369

Sokal RR, Rohlf FJ (1981) Biometry, 2nd edn. WH Freeman \& $\mathrm{Co}$, San Fransisco

Thistle D (1981) Natural physical disturbances and communi-

This article was presented by C. H. Peterson (Senior Editorial Advisor), Morehead City, N. Carolina, USA. ties of marine soft bottoms. Mar Ecol Prog Ser 6:223-228

Thistle D (1988) A temporal difference in harpacticoid-copepod abundance at a deep-sea site: caused by benthic storms? Deep Sea Res 35:1015-1020

Thistle D, Yingst JY, Fauchald K (1985) A deep-sea benthic community exposed to strong near-bottom currents on the Scotian Rise (Western Atlantic). Mar Geol 66:91-112

Van Blaricom GR (1982) Experimental analysis of structural regulation in a marine sand community exposed to oceanic swell. Ecol Monogr 52:283-285

Verlaan PA (1992) Benthic recruitment and manganese crust formation on seamounts. Mar Biol 113:171-174

Wichman CA, Eriksen CC, Bogue NM, Brink KH, Frye DE, Pillsbury RD, Pittock GM, Tarbell SA (1993) Fieberling Guyot moored array data. University of Washington, School of Oceanography. Technical Report A93-1, Seattle Wilson WH Jr (1991) Sexual reproductive modes in polychaetes: classification and diversity. Bull mar Sci 48:500-516

Manuscript first received: October 10, 1994 Revised version accepted: February 7, 1995 